\title{
INFLUENCE OF CULTIVATION METHODS ON PRODUCTIVITY AND STORAGE QUALITY OF SOME EGYPTIAN ONION CULTIVARS. \\ Moustafa, Y.M.M. ${ }^{\star}$; M.G. Morsy ${ }^{\star \star}$ and R.A. Marey ${ }^{\star \star}$ \\ * Horticulture Dept., Faculty of Agric., Minia University, Minia, Egypt. \\ ** Onion Res. Dept., Field Crops Res. Inst., Agric. Res. Center, Giza, Egypt.
}

\begin{abstract}
Two field experiments were conducted during the two successive seasons of 2007/2008 and 2008/2009, at Sids Agricultural Research Station, Bani Sweif Governorate. The objectives of this investigation was aimed to studies productivity and storage quality of some onion cultivars i.e. (Shandaweel 1, Giza 6 Mohassan and Giza 20), when cultivated by two cultivating methods (using sets and seedlings), and using three onion cultivars under Middle Egypt conditions.

The obtained results could be summarized as the following:

1. The shortest season was obtained by Shandaweel 1 cultivar followed by Giza 6 Mohassan while Giza 20 appeared the longest season, in both seasons. Giza 20 cultivar appeared the highest values of average bulb weight and single bulbs\%, while Shandaweel 1 cultivar appeared the lowest values. Giza 20 cultivar attained the lowest values of double bulbs\%, while Shandaweel 1 attained the highest values. Giza 6 Mohassan appeared the minimum values of bolter\%, whereas shandaweel1 appeared the maximum values. The maximum values of marketable yield/fed and total yield/fed were obtained by Giza 20 cultivar, while the lowest values were obtained by Shandaweel 1.

2. Planting onion by seedlings gave higher values of average bulb weight and single bulbs\% as compared to planting by sets in both seasons. Seedlings cultivating method gave lower values of double bulbs $\%$ and bolters $\%$ as compared to sets cultivating method. The values of marketable yield/fed and total bulb yield/fed of onion under seedlings cultivating method surpassed those under sets cultivating method

3. The lowest values of decayed and sprouted bulbs\% were obtained by the combination between seedlings cultivating method and Giza 6 Mohassan, at all storage periods in both seasons, except for this at 180 days in the first season.

4. Cultivating onion by seedling and using Giza 6 Mohassan cultivar attained the lowest values of bulbs weight loss\% at all storage periods, in both seasons.

5. The interaction between onion cultivars and method of cultivation significantly affected single bulbs \%, average bulb weight ( $\mathrm{gm})$, bolters \% and infected bulb.

It could be concluded that for maxi mixing onion yield and it is quality during storage by cultivation of Giza 20 cultivar using seedlings method under cultivation of Bani Sweif Governorate.
\end{abstract}

\section{INTRODUCTION}

Onion (Allium cepa L.) is amongst the main vegetable crops in Egypt for consumption, processing and exportation. It is one of the important sources for hard currency, due to the early availability of the crop for foreign markets as well as its higher quality compared to other onions. Method of onion planting is also promising for the possibly of exportation and for the 
dehydration industry as well (Baghdady, 2008). The size and keeping quality of the produced onions are much better when planting seedlings rather than sets. Great attention should be paid to improve sets planting method and to study the factors which affect the plants and their characters during the vegetative (Abd El-Fattah et al., 1983).

Evaluation of onion cultivars have been carried out all over the world. The traditional varieties are still produced in certain regions due to their high quality and acceptanceat local and foreign markets (Casallo et al., 1991). Leilah et al. (2003) stated that local onion strains markedly differed in most of growth and yield characteristics, Moshtohor and South El-Tahrir strains gave the highest marketable and total bulb yields / ha, followed by the New nucleus 961 strain. El-Shafie et al. (1971) reported that the yields of Behairy cultivar were higher than those of Giza 6 Mohassan. Belnarz and Kadams (1991) in Nigeria, evaluated exotic onion cultivars and 23 local cultivars. They showed that there were wide differences among the obtained yields (4.77-12.64 $\mathrm{t} / \mathrm{ha})$. Pavolic et al. (2002), in Serbia and Montenegro, indicated that the values of mean bulb weight for 10 cultivars varied from 55.91 to $105.3(\mathrm{~g})$.

Another onion criterion for onion bulb characterizations is storage quality. The storage life of onion is limited mainly due to sprouting and rotting, therefore, it can't be stored for longer periods (Adamicki, 1998). After harvest, onions are in a natural state of dormancy (Jones and Man, 1963). Length of the dormant period varies with cultivars and storage temperatures (Miedema, 1994). The important features of onion cultivars useful for cultivation from sets are low tendency to bolting and good keeping quality (Tendaj and Gruszecki, 2005). Smittle (1988) reported that the quantity of marketable bulbs decreased by $12.25 \%$ per month when storing at room temperature. Patil and Kale (1991) assessed the storability of 12 cultivars. They reported that losses after 6 months varied from 29.25 to $94.00 \%$.

The present investigation was aimed to study the productivity and storage ability of three Egyptian onion cultivars, planted under two cultivating methods, in the Middle Egypt.

\section{MATERIALS AND METHODS}

This study was carried out at the farm of Sids Agricultural Research Station, Bani Sweif Governorate, Egypt, during 2007/2008 and 2008/2009 seasons. The experiment was laid out in split plot design with four replications. The two cultivating methods (sets and seedlings) were allocated in the main plots, whereas the three onion cultivars (Shandaweel 1, Giza 6 Mohassan, and Giza 20) were assigned to sub plots. Seeds of the three cultivars were cultivated in a nursery in beginning of January during 2007 and 2008 and were left till the beginnings of May of the same year to get the onion sets. After maturity, the plants were harvested and left for curing; then, sets of $16-20 \mathrm{~mm}$ in diameter were selected and cultivated in the field at the 15 and $18^{\text {th }}$ of September of 2007 and 2008, respectively. The onion sets cultivated at the two sides of the ridges with $7 \mathrm{~cm}$ apart between sets $(50$ bulbs were cultivated in each side). From the other hand, onion seeds of the 
three cultivars were sown in the nursery at the same farm at the 5 and $8 \mathrm{th}$ of September to obtain seedlings, which were transplanted in the field at the 4 and 11 th of November, in the first and second seasons, respectively. The seedlings were cultivated at the two sides of the ridges with $7 \mathrm{~cm}$ apart between seedlings (50 bulbs were cultivated in each side). Each plot contained 3 ridges and three hundreds of sets or seedlings. The plot area was $5.25 \mathrm{~m}^{2}(3.5 \times 1.5 \mathrm{~m})$. The soil of the experimental field was clay. All recommended procedure for onion cultivation were followed.

\section{Studied characters:}

1. No of days to maturity: Number of days from transplanting to bulb maturity was counted. Maturity stage was determined based on both softening of bulb neck and $50 \%$ top-down of bulb leaves.

2. Average bulb weight (g): It was calculated by dividing weight of single bulbs by its number.

3. Percentage of single bulbs: It was estimated by dividing number of single bulbs by the total number of bulbs $\times 100$.

4. Percentage of double bulbs: It was estimated by dividing number of double bulbs by the total number of bulbs $x 100$.

5. Percentage of bolters: Plants that showed annual bolting in each sub plot were counted and percentages of bolters were calculated.

6. Percentage of infected bulbs: All infected or unhealthy onion bulbs from each sub plot were counted to calculate percentage of infected bulbs.

7. Marketable yield (ton/fed): It was calculated on basis of marketable yield for the experimental plot in tons/fed.

8. Culls yield (ton/fed): It includes bulbs of less than $3 \mathrm{~cm}$ diameter, doubles, bolters, off-color and scallions.

9. Total yield (ton/fed): It was calculated on basis of yield for the experimental plot in tons/fed.

10. The following characters were recorded at 60 days intervals on the stored bulbs:

- Decayed and sprouted bulbs percentage =

(number of decayed and sprouted bulbs) $\times 100$

total number of bulbs at beginning of storage

- Bulbs weight loss percentage $=$

(weight loss of bulbs) $\times 100$

total bulbs weight at beginning of storage

\section{Statistical analysis:}

The collected data were subjected to proper statistical analysis of split plot design according to the procedure outlined by Snedecor and Cochran (1980). Means were compared using the L.S.D. at $5 \%$ level of significance according to Gomez and Gomez (1984). 


\section{RESULTS AND DISCUSSION}

\section{Number of days to maturity:}

Results in table (1) showed the effect of cultivating methods, onion cultivars and their interaction on number of days to maturity. The results revealed that number of days to maturity was insignificantly affected by cultivating methods in both seasons.

The studied onion cultivars differed significantly in studied characters in both seasons. The shortest season was obtained by Shandaweel 1 cultivar (113.00 and 109.38 days) followed by Giza 6 Mohassan (125.38 and 124.88 days) while Giza 20 appeared the longest season (145.50 and 143.13 days), in the first and second seasons, respectively. These findings may attributed to the genetically differences between these cultivars. The differences between onion genotypes in respect to number of days to maturity were recorded by several investigations (Leilah et al., 2003; Marey and Morsy, 2010; and Morsy et al., 2011).

Data also revealed to that the effect of the interaction between cultivating methods and cultivars on number of days to maturity did not reach the level of significance, in both seasons.

\section{Average bulb weight $(g)$ :}

Results in Table (1) revealed that average bulb weight was significantly affected by cultivating methods during the two seasons. Planting onion by seedlings gave higher values of average bulb weight as compared to planting by sets in both seasons.

There was a significant difference in average of bulb weight due to onion cultivars in both seasons. Giza 20 cultivar appeared the highest values of average bulb weight (110.51 and $115.21 \mathrm{~g}$ in the first and second seasons, respectively), while Shandaweel 1 cultivar appeared the lowest values (73.58 and $74.46 \mathrm{~g}$ in the first and second seasons, respectively). These results may be attributed to the extended growth life for Giza 20 cultivar as compared to other cultivars. Previous investigations of Mohanty and Prusti (2001) and Leilah et al. (2003) revealed to the differences between onion genotypes in respect to average bulb weight.

Results in Tables (1) show that the interaction between planting methods and cultivars was significant only in the second season. The maximum values of average bulb weight were observed under seedlings planting when cultivated with Giza 20 cultivar in the first seasons, or under sets planting when cultivated with Giza 20 in the second season.

\section{Single bulbs percentage:}

Cultivating methods had a significant effect on single bulbs\% in both seasons. Single bulbs\% of onion under seedlings cultivation was higher as compared to those cultivated by sets in both seasons. This character was recommended by onion farmers (to produce high onion bulbs quality suitable for marketing) and consumers (for kitchen use and storage) than the doubled bulbs.

The results presented in table (1), it is clear that different cultivars had significant effect on single bulbs\% in both seasons. Giza 20 onion cultivar 
attained the highest values of single bulbs\% (81.55 and $81.86 \%)$, while Shandaweel 1 attained the lowest values (52.35 and 51.70\%), in the first and second seasons, respectively.

Regarding the interaction effect on single bulbs\%, it could be noticed that this character was significantly affected by the interaction between the two factors in the first season only. Highest percentage of single bulbs were obtained under set cultivating method when cultivated with Giza 20 cultivar in the first season, and under seedling cultivating method when cultivated with Giza 20 in the second season.

Table 1: Means of No of days to maturity, average bulb weight and single bulbs \% as affected by two cultivating methods and three onion cultivars and their interaction during 2007/2008 and 2008/2009 seasons.

\begin{tabular}{|c|c|c|c|c|c|c|c|}
\hline \multirow[b]{2}{*}{$\begin{array}{l}\text { Cultivat. } \\
\text { methods }\end{array}$} & \multirow[b]{2}{*}{ Cultivars } & \multicolumn{3}{|c|}{$2007 / 2008$} & \multicolumn{3}{|c|}{$2008 / 2009$} \\
\hline & & $\begin{array}{c}\text { No of } \\
\text { days to } \\
\text { matur. }\end{array}$ & $\begin{array}{c}\text { Aver. } \\
\text { bulb } \\
\text { weig. (g) }\end{array}$ & $\begin{array}{c}\text { Single } \\
\text { bulbs \% }\end{array}$ & $\begin{array}{l}\text { No of } \\
\text { days to } \\
\text { matur. }\end{array}$ & $\begin{array}{c}\text { Aver. } \\
\text { bulb } \\
\text { weig. (g) }\end{array}$ & $\begin{array}{c}\text { Single } \\
\text { Bulbs } \\
\%\end{array}$ \\
\hline \multirow{3}{*}{ Sets } & Shandaweel 1 & 116.75 & 66.23 & 47.79 & 112.25 & 63.38 & 48.08 \\
\hline & Giza 6 Mohass. & 126.75 & 81.95 & 70.71 & 123.25 & 85.65 & 69.85 \\
\hline & Giza 20 & 150.00 & 104.63 & 83.22 & 146.75 & 115.23 & 79.43 \\
\hline \multicolumn{2}{|l|}{ Mean } & 131.17 & 84.27 & 67.24 & 127.42 & 88.08 & 65.79 \\
\hline \multirow{3}{*}{ Seedlings } & Shandaweel 1 & 109.25 & 80.93 & 56.91 & 106.50 & 85.55 & 55.32 \\
\hline & Giza 6 Mohass. & 124.00 & 95.45 & 81.05 & 126.50 & 105.38 & 80.98 \\
\hline & Giza 20 & 141.00 & 116.40 & 79.88 & 139.50 & 115.20 & 84.28 \\
\hline \multicolumn{2}{|l|}{ Mean } & 124.75 & 97.59 & 72.61 & 124.17 & 102.04 & 73.52 \\
\hline \multirow{3}{*}{$\begin{array}{l}\text { Means for } \\
\text { cultivars }\end{array}$} & Shandaweel 1 & 113.00 & 73.58 & 52.35 & 109.38 & 74.46 & 51.70 \\
\hline & Giza6 Mohass. & 125.38 & 88.70 & 75.88 & 124.88 & 95.51 & 75.41 \\
\hline & Giza 20 & 145.50 & 110.51 & 81.55 & 143.13 & 115.21 & 81.86 \\
\hline \multirow{3}{*}{ L.S.D. 5\% } & Cult. methods & NS & 10.70 & 3.65 & NS & 10.07 & 3.95 \\
\hline & Cultivars & 4.28 & 7.89 & 2.88 & 6.26 & 6.16 & 3.74 \\
\hline & Interaction & NS & NS & 4.08 & NS & 8.72 & NS \\
\hline
\end{tabular}

4. Double bulbs percentage:

It is clear from results presented in Table (2) that percentage of double bulbs was significantly affected by the two cultivating methods, in the two seasons, where the seedlings cultivating method gave lower percentage of double bulbs as compared to sets cultivating method. The double bulbs initiation could be explained in view of that the onion bulb consists of a short underground stem with fleshy scale leaves which develop the terminal bud, where, lateral buds either remain dormant during the vegetative phase of the plant life cycle, or they develop into multi-hearted bulbs which sometimes double.

The results in Table (2) clearly show that onion cultivars differed significantly percentage of double bulbs in both seasons. Giza 20 cultivar attained the lowest percentage of double bulbs (9.22 and 9.87\%), while Shandaweel 1 attained the highest percentages (23.55 and $21.43 \%$ ), in the first and second seasons respectively. These results might be attributed to genetic variation between the onion cultivars in respect to this character. The 


\section{El-Feki,T.A. et al.}

differences between onion genotypes in respect to double bulbs\% were reported by Gamie and Yaso (2007).

Concerning the interaction effect on percentage of double bulbs, it was noticed that this character was significantly affected by the interaction between cultivating methods and cultivars in the second seasons only. Cultivating onion by seedlings when using Giza 20 appeared the lowest values of double bulbs\%, in both seasons.

\section{Bolters percentage:}

The results presented in Table (2) indicated that cultivating methods affected significantly on bolters\% in the second season only. Seedling cultivating method gave lower percentage of bolters (11.56 and $11.31 \%$ ), as compared to sets cultivating method (11.76 and 13.38\%) in the first and second seasons, respectively. This finding is in line with that obtained by ElMofty et al. (1983) who revealed that the sets are considered small bulbs and have the tendency to bolt more easily than the transplants which did not enter yet in bulbing stage.

The results show that bolters\% of onion bulbs was significantly responded to cultivars in both seasons. Giza 6 Mohassan appeared the minimum percentage of bolters $(6.08$ and $5.49 \%)$, whereas shandaweel 1 appeared the maximum values (22.49 and $25.70 \%)$ in the first and second seasons, respectively. The differences between onion genotypes in respect to bolters\% were reported by Lancaster et al., (1995) and Cheema et al., (2003) who evaluated some of onion cultivars and they revealed that those cultivars had significant differences in bolting\%.

The combination between the two studied factors significantly affected bolters\% in onion bulbs, in both seasons (Table 2). Under sets cultivating method, Giza 20 cultivar had the lowest percentage of bolters (2.28 and $4.17 \%$ ), while, under seedlings cultivating method, Giza 6 Mohassan had the lowest percentage (5.12 and $4.66 \%)$ in the first and second seasons, respectively.

\section{Infected bulbs percentage:}

Infected bulbs\% was significantly affected by cultivating methods in the second season only (Table 2). The seedlings cultivating method gave lower percentage of infected bulbs as compared to sets cultivating method, in both seasons. This result could be attributed to that the onion bulbs which were produced under sets cultivating method were fleshier than those produced under seedling cultivating method, which exposed the bulbs to the infection with different pathogen agents.

It is clear from results percentage in Table (2) that infected bulbs\% was significantly affected by the three tested cultivars in the two seasons. Giza 6 Mohassan cultivar appeared the lowest percentage of infected bulbs (1.07 and $0.99 \%$ ), while Giza 20 cultivar appeared the highest percentage (2.81 and $2.37 \%$ ) in the first and second seasons, respectively.

Percentage of infected bulbs was significantly affected by the interaction between cultivating methods and cultivars in both seasons (Table 2). This character was low for the three cultivars under the two cultivating methods, as it ranged from $0.72 \%$ for Shandaweel 1 under seedlings 
cultivation in the second season, to $4.01 \%$ for Giza 20 under sets cultivation in the first seasons.

Table 2: Percentage of double bulbs, bolters and infected bulbs as affected by of two cultivating methods and three onion cultivars and their interaction during $2007 / 2008$ and $2008 / 2009$ seasons.

\begin{tabular}{|c|c|c|c|c|c|c|c|}
\hline \multirow[b]{2}{*}{$\begin{array}{l}\text { Cultivat. } \\
\text { methods }\end{array}$} & \multirow[b]{2}{*}{ Cultivars } & \multicolumn{3}{|c|}{$2007 / 2008$} & \multicolumn{3}{|c|}{$2008 / 2009$} \\
\hline & & $\begin{array}{l}\text { Double } \\
\text { bulbs } \%\end{array}$ & $\begin{array}{c}\text { Bolters } \\
\%\end{array}$ & $\begin{array}{l}\text { Infected } \\
\text { bulbs } \%\end{array}$ & $\begin{array}{l}\text { Double } \\
\text { bulbs } \%\end{array}$ & Bolters \% & $\begin{array}{l}\text { Infected } \\
\text { bulbs } \%\end{array}$ \\
\hline \multirow{3}{*}{ Sets } & Shandaweel 1 & 24.97 & 25.95 & 1.28 & 20.62 & 29.67 & 1.62 \\
\hline & Giza 6 Mohass. & 20.88 & 7.05 & 1.36 & 22.78 & 6.31 & 1.06 \\
\hline & Giza 20 & 10.49 & 2.28 & 4.01 & 13.17 & 4.17 & 3.23 \\
\hline \multicolumn{2}{|l|}{ Mean } & 18.78 & 11.76 & 2.22 & 18.86 & 13.38 & 1.97 \\
\hline \multirow{3}{*}{$\begin{array}{l}\text { Seedling } \\
\mathbf{s}\end{array}$} & Shandaweel 1 & 22.13 & 19.02 & 1.94 & 22.24 & 21.73 & 0.72 \\
\hline & Giza 6 Mohass. & 13.07 & 5.12 & 0.78 & 13.44 & 4.66 & 0.92 \\
\hline & Giza 20 & 7.96 & 10.56 & 1.61 & 6.58 & 7.54 & 1.51 \\
\hline \multicolumn{2}{|l|}{ Mean } & 14.39 & 11.56 & 1.44 & 14.09 & 11.31 & 1.05 \\
\hline \multirow{3}{*}{$\begin{array}{l}\text { Means } \\
\text { for } \\
\text { cultivars }\end{array}$} & Shandaweel 1 & 23.55 & 22.49 & 1.61 & 21.43 & 25.70 & 1.17 \\
\hline & Giza6 Mohass. & 16.97 & 6.08 & 1.07 & 18.11 & 5.49 & 0.99 \\
\hline & Giza 20 & 9.22 & 6.42 & 2.81 & 9.87 & 5.85 & 2.37 \\
\hline \multirow{3}{*}{ L.S.D. 5\% } & Cult. Methods & 2.40 & NS & NS & 3.82 & 1.20 & 0.46 \\
\hline & Cultivars & 2.40 & 2.32 & 1.03 & 3.62 & 3.21 & 0.56 \\
\hline & Interaction & NS & 3.28 & 1.45 & 5.13 & 4.54 & 0.79 \\
\hline
\end{tabular}

7. Marketable yield (ton/fed):

Results presented in table (3) showed that cultivating methods significantly affected marketable yield/fed in both seasons. Marketable yield/fed of onion under seedlings cultivating method surpassed those under sets cultivating method by 23.22 and 26.31 in the first and second seasons, respectively. Similar result was obtained by El-Mofty et al. (1983) who indicated that transplanting resulted in a high marketable yield compared with sets.

Studied onion cultivars differed significantly in marketable yield/fed in both seasons as shown in Table (3). Maximum marketable yield/fed (19.37 and 18.79 ton/fed) were obtained by Giza 20 cultivar, while the lowest (9.59 and 8.56 ton/fed) was obtained by Shandaweel 1, in the first and second seasons, respectively. The significant differences between studied onion cultivars may be due to their significant performance in some other traits such as single bulbs $\%$, double bulbs $\%$, bolters $\%$ and infected bulbs $\%$ that were discussed previously. These results were in accordance with those found by Mohamed and Gamie (2000) who reported that Giza 20 cultivar produced the highest values of marketable yield, while Shandaweel 1 cultivar produced the lowest values as compared with other cultivars.

The effect of the interaction between the two studied factors on marketable yield/fed did not reach the levels of significance in both seasons.

\section{Culls yield (ton/fed):}

The results presented in Table (3) reported that cultivating methods significantly affected culls yield/fed in the first season only. Seedlings cultivating method gave lower culls yield/fed as compared to sets cultivating method, in both seasons. The significant differences between onion studied 
cultivating methods may be due to the significant performance of this factor on some other traits such as single bulbs $\%$, double bulbs $\%$, bolters $\%$ and infected bulbs\% as mentioned above.

The results in Table (3) clearly revealed that culls yield/fed was significantly affected by cultivars, in both seasons. Giza 20 cultivar gave the lowest cull yield/fed (4.26 and 3.88 ton/fed), while Sandaweel 1 gave the highest cull yield/fed (6.14 and 6.81 ton/fed), in the first and second seasons, respectively. These results may be due to the genetic variation between the studied cultivars. Similar result was recorded by Mohamed and Gamie (1999) who cleared that Giza 20 onion variety produced the lowest amount of culls yield/fed.

The interaction between the two studied factors significantly affected culls yield/fed in the first season only. The minimum culls yield/fed was obtained under seedlings cultivating method when cultivated with Giza 20 cultivar in both seasons.

\section{Total yield (ton/fed):}

The results in Table (3), indicated that total bulb yield/fed was significantly affected by cultivating methods in both seasons. Total bulbs yield/fed under seedlings cultivating method exceeded those under sets cultivating method by 11.73 and $13.05 \%$, in the first and second seasons respectively. On the contrary, El-Mofty et al. (1983) stated that the different planting methods for onion did not show any effect on the total bulb yield.

Table 3: Marketable yield, culls yield and total yield as effected by of two cultivating methods and three onion cultivars and their interaction during $2007 / 2008$ and $2008 / 2009$ seasons.

\begin{tabular}{|c|c|c|c|c|c|c|c|}
\hline \multirow[b]{2}{*}{$\begin{array}{l}\text { Cultivat. } \\
\text { methods }\end{array}$} & \multirow[b]{2}{*}{ Cultivars } & \multicolumn{3}{|l|}{$2007 / 2008$} & \multicolumn{3}{|c|}{$2008 / 2009$} \\
\hline & & $\begin{array}{c}\text { Market. } \\
\text { yield } \\
\text { (ton/fed) }\end{array}$ & \begin{tabular}{|c|} 
Culls \\
yield \\
(ton/fed)
\end{tabular} & $\begin{array}{c}\text { Total yield } \\
\text { (ton/fed) }\end{array}$ & $\begin{array}{c}\text { Market. } \\
\text { yield } \\
\text { (ton/fed) }\end{array}$ & $\begin{array}{c}\text { Culls } \\
\text { yield } \\
\text { (ton/fed) }\end{array}$ & $\begin{array}{c}\text { Total yield } \\
\text { (ton/fed) }\end{array}$ \\
\hline \multirow{3}{*}{ Sets } & Shandaweel 1 & 7.88 & 5.84 & 13.72 & 6.96 & 7.60 & 14.56 \\
\hline & Giza 6 Mohass. & 14.74 & 7.00 & 21.74 & 13.90 & 5.14 & 19.04 \\
\hline & Giza 20 & 17.94 & 4.92 & 22.86 & 18.02 & 4.02 & 22.04 \\
\hline \multicolumn{2}{|l|}{ Mean } & 13.52 & 5.92 & 19.44 & 12.96 & 5.59 & 18.55 \\
\hline \multirow{3}{*}{ Seedlings } & Shandaweel 1 & 11.30 & 6.44 & 17.74 & 10.16 & 6.02 & 16.18 \\
\hline & Giza 6 Mohass. & 17.89 & 5.00 & 23.02 & 19.38 & 4.04 & 23.42 \\
\hline & Giza 20 & 20.80 & 3.60 & 24.40 & 19.56 & 3.74 & 23.30 \\
\hline \multicolumn{2}{|l|}{ Mean } & 16.66 & 5.01 & 21.72 & 16.37 & 4.60 & 20.97 \\
\hline \multirow{3}{*}{$\begin{array}{l}\text { Means for } \\
\text { cultivars }\end{array}$} & Shandaweel 1 & 9.59 & 6.14 & 15.73 & 8.56 & 6.81 & 15.37 \\
\hline & Giza6 Mohass. & 16.31 & 6.00 & 22.38 & 16.64 & 4.59 & 21.23 \\
\hline & Giza 20 & 19.37 & 4.26 & 23.63 & 18.79 & 3.88 & 22.67 \\
\hline \multirow{3}{*}{ L.S.D. 5\% } & Cult. methods & 0.34 & 0.75 & 0.88 & 0.58 & NS & 1.03 \\
\hline & Cultivars & 1.37 & 0.87 & 1.61 & 1.66 & 0.94 & 2.03 \\
\hline & Interaction & NS & 1.23 & NS & NS & NS & NS \\
\hline
\end{tabular}

Results in Table (3) showed that studied onion cultivars differed significantly in respect to total bulb yield/fed. Giza 20 cultivar produced the greatest total yield/fed (23.63 and 22.67 ton/fed), while Shandaweel 1 cultivar produced the smallest total yield/fed (15.73 and15.37 ton/fed) in the first and 
second seasons, respectively. These differences in total bulb yield/fed may be due to genetic variation between these cultivars which affected on the efficiency of the utilization for different environmental resources. These results were in agreement with those found by Mohamed and Gamie (1999), Mohamed and Gamie (2000) and El-Damarany and Obiadalla (2005).

Results presented in Table (3) revealed that the interaction between cultivating methods and cultivars on total bulb yield/fed did not reach the level of significance, in both seasons.

10. Decayed and sprouted bulbs percentage:

Results in Table (4) clearly indicated that the effect of cultivating methods on decayed and sprouted\% was significant at all storage period $(60$, 120 and 180 days), in both seasons. The percentage of decayed and sprouted of onion bulbs was lower under seedlings cultivating method as compared to sets cultivating method. These results were true at all storage periods, in both seasons. The percentage of decayed and sprouted bulbs under sets cultivating method ranged from $32.53 \%$ (at 60 days storage period) to $88.56 \%$ (at 180 days storage period) and from $26.33 \%$ (at 60 days storage period) to $89.86 \%$ (at 180 days storage period), in the first and second seasons, respectively. Whereas, percentages of decayed and sprouted bulbs under seedlings cultivating method ranged from $12.49 \%$ (at 60 days storage period) to $66.99 \%$ (at 180 days storage period) and from $11.86 \%$ (at 60 days storage period) to $66.67 \%$ (at 180 days storage period), in the first and second seasons, respectively. These results mainly due to the higher resistance of bulbs produced by seedlings to fungal diseases as compared to those produced by sets. Similar results were obtained by ElMofty et al. (1983) who reported that bulbs produced from the transplanting method had thin necks than those produced by sets, and that restricted the fungus infection to a certain extent.

Table 4: Percentages of decayed and sprouted bulbs at three storage periods as effected by two cultivating methods and three onion cultivars and their interaction during 2007/2008 and 2008/2009 seasons.

\begin{tabular}{|c|c|c|c|c|c|c|c|}
\hline \multirow{3}{*}{$\begin{array}{l}\text { Cultivat. } \\
\text { methods }\end{array}$} & \multirow{3}{*}{ Cultivars } & \multicolumn{3}{|c|}{$2007 / 2008$} & \multicolumn{3}{|c|}{$2008 / 2009$} \\
\hline & & \multicolumn{3}{|c|}{ Decayed and sprouted bulbs \% } & \multicolumn{3}{|c|}{ Decayed and sprouted bulbs \% } \\
\hline & & 60 days & 120 days & 180 days & 60 days & 120 days & 180 days \\
\hline \multirow{3}{*}{ Sets } & Shandaweel 1 & 31.68 & 56.31 & 96.84 & 27.11 & 49.45 & 94.22 \\
\hline & Giza 6 Mohass. & 31.00 & 63.78 & 93.85 & 20.91 & 50.30 & 91.32 \\
\hline & Giza 20 & 34.91 & 49.08 & 75.00 & 30.98 & 44.93 & 84.04 \\
\hline \multicolumn{2}{|l|}{ Mean } & 32.53 & 56.39 & 88.56 & 26.33 & 48.23 & 89.86 \\
\hline \multirow{3}{*}{ Seedlings } & Shandaweel 1 & 17.19 & 34.32 & 80.08 & 10.57 & 27.10 & 72.91 \\
\hline & Giza 6 Mohass. & 8.76 & 23.99 & 62.52 & 7.78 & 17.35 & 57.04 \\
\hline & Giza 20 & 11.51 & 27.79 & 58.37 & 17.26 & 27.39 & 70.06 \\
\hline \multicolumn{2}{|l|}{ Mean } & 12.49 & 28.70 & 66.99 & 11.86 & 23.95 & 66.67 \\
\hline \multirow{3}{*}{$\begin{array}{l}\text { Means for } \\
\text { cultivars }\end{array}$} & Shandaweel 1 & 24.44 & 45.31 & 88.46 & 18.84 & 38.27 & 83.57 \\
\hline & Giza6 Mohass. & 19.88 & 43.89 & 78.19 & 14.34 & 33.83 & 74.18 \\
\hline & Giza 20 & 23.21 & 38.43 & 66.69 & 24.11 & 36.16 & 77.05 \\
\hline \multirow{3}{*}{ L.S.D. 5\% } & Cult. methods & 5.09 & 1.78 & 4.86 & 4.51 & 4.57 & 4.00 \\
\hline & Cultivars & NS & 5.52 & 6.89 & 4.46 & NS & 5.19 \\
\hline & Interaction & NS & 7.81 & NS & NS & 6.84 & 7.33 \\
\hline
\end{tabular}




\section{El-Feki,T.A. et al.}

For the effect of cultivars, results in Table (4) showed that the different varieties had significant effect on percentage of decayed and sprouted bulbs at 60 days storage period in the second season, at 120 days in the first season and at 180 days in both seasons. Giza 6 Mohassan cultivar appeared the lowest percentages of decayed and sprouted bulbs at 60 days in both seasons and at each of 120 and 180 days in the second seasons. While, Giza 20 cultivar appeared the lowest percentages at each of 120 and 180 days in the first seasons.

Results in Table (4) revealed that the interaction between the two studied factors significantly affected percentages of decayed and sprouted bulbs at 120 days in both seasons and at 180 days in the second season. The lowest percentages of decayed and sprouted bulbs were obtained by the combination between seedlings cultivating method and Giza 6 Mohassan, at all storage period in both seasons, except for this at 180 days in the first season.

\section{1- Bulbs weight loss percentage:}

The results in Table (5) showed that percentage of bulb weight loss was significantly affected by cultivating methods at all storage periods $(60$, 120 and 180 days), in both seasons. The percentages of bulbs weight loss were lower under seedlings cultivating method as compared to sets cultivating method, at all storage periods, in both seasons. The percentages of bulbs weight loss under sets cultivating method ranged from $36.45 \%$ (at 60 days storage period) to $90.87 \%$ (at 180 days storage period) and from $26.95 \%$ (at 60 days storage period) to $90.02 \%$ (at 180 days storage period), in the first and second seasons, respectively. Whereas, these values under seedlings cultivating method ranged from $15.38 \%$ (at 60 days storage period) to $73.09 \%$ (at 180 days storage period) and from $12.62 \%$ (at 60 days storage period) to $72.69 \%$ (at 180 days storage period), in the first and second seasons, respectively.

The studied onion cultivars significantly differed in bulb weight loss\%, at all storage periods, in both seasons (Table 5). Giza 6 Mohassan cultivar showed minimum percentages of weight loss at 60 days storage period in both seasons and at 120 days in the second season. While, Giza 20 cultivar showed the lowest percentages of weight loss at 120 days storage period in the first season and at 180 days in both seasons. These differences in percentages of bulbs weight loss may be attributed to the genetic differences between the tested onion cultivars. The differences between onion genotypes in respect to bulbs weight loss\% were reported by many investigators such as Gamie et al., 2000; Leilah et al., 2003; and Gamie and yasso, 2007.

The interaction between cultivating methods and onion cultivars significantly affected percentages of bulbs weight loss at 60 and 120 days of storage periods in the first season and at 180 days, in both seasons. Cultivating Giza 6 Mohassan cultivar by seedling attained the lowest percentages of bulbs weight loss at all storage periods, in both seasons. 
Table 5: Percentages of bulbs weight loss at three storage periods as effected by two cultivating methods and three onion cultivars and their interaction during $2007 / 2008$ and $2008 / 2009$ seasons.

\begin{tabular}{|c|c|c|c|c|c|c|c|}
\hline \multirow{3}{*}{$\begin{array}{l}\text { Cultivat. } \\
\text { methods }\end{array}$} & \multirow{3}{*}{ Cultivars } & \multirow{2}{*}{\multicolumn{3}{|c|}{\begin{tabular}{|c|}
$2007 / 2008$ \\
bulbs weight loss $\%$
\end{tabular}}} & \multirow{2}{*}{\multicolumn{3}{|c|}{\begin{tabular}{|c|}
$2008 / 2009$ \\
bulbs weight loss $\%$ \\
\end{tabular}}} \\
\hline & & & & & & & \\
\hline & & 60 days & 120 days & 180 days & 60 days & 120 days & 180 days \\
\hline \multirow{3}{*}{ Sets } & Shandaweel 1 & 34.89 & 57.05 & 97.13 & 27.65 & 51.99 & 95.88 \\
\hline & Giza 6 Mohass. & 32.30 & 67.60 & 96.75 & 22.11 & 47.23 & 92.31 \\
\hline & Giza 20 & 42.17 & 51.34 & 78.73 & 31.11 & 48.78 & 81.86 \\
\hline \multicolumn{2}{|l|}{ Mean } & 36.45 & 58.66 & 90.87 & 26.95 & 49.33 & 90.02 \\
\hline \multirow{3}{*}{ Seedlings } & Shandaweel 1 & 21.88 & 51.15 & 82.20 & 11.47 & 28.49 & 78.43 \\
\hline & Giza 6 Mohass. & 10.35 & 31.03 & 67.16 & 9.69 & 22.37 & 64.67 \\
\hline & Giza 20 & 13.92 & 40.48 & 69.90 & 16.69 & 32.97 & 74.98 \\
\hline \multicolumn{2}{|l|}{ Mean } & 15.38 & 40.88 & 73.09 & 12.62 & 27.94 & 72.69 \\
\hline \multirow{3}{*}{$\begin{array}{l}\text { Means for } \\
\text { cultivars }\end{array}$} & Shandaweel 1 & 28.39 & 54.10 & 89.66 & 19.56 & 40.24 & 87.15 \\
\hline & Giza6 Mohass. & 21.32 & 49.31 & 81.96 & 15.90 & 34.80 & 78.49 \\
\hline & Giza 20 & 28.04 & 45.91 & 74.32 & 23.90 & 40.88 & 78.42 \\
\hline \multirow{3}{*}{ L.S.D. 5\% } & Cult. methods & 4.99 & 9.01 & 6.55 & 4.59 & 6.83 & 5.56 \\
\hline & Cultivars & 2.97 & 5.20 & 5.20 & 5.49 & 4.18 & 4.11 \\
\hline & Interaction & 4.21 & 7.36 & 7.36 & NS & NS & 5.81 \\
\hline
\end{tabular}

\section{REFERENCES}

Abd El-Fattah, M.A.; I.A. El-Mofty; M.A. Badawi and E.M. Agwah (1983). Effect of planting date, spacing and set size on the morphological characters of onion plants. Agricultural Research Review, 61 (8): 225-249.

Adamicki, F. (1998). Comparison of quality and storage ability in some onion cultivars. Biuletyn Warzywniczy, 48: 89-100.

Baghdady, G.A. (2008). Growth and yield components of onion grown by sets as affected by sowing time and seed size under Assiut conditions. M.Sc. Thesis, Fac. Agric., Assiut Univ.

Belnarz, F. and A. Kadams (1991). Yield and quality of transplanted onion (Allium cepa L.) in Nigeria as influenced by variety, sowing date and other factors. Beitrage zur Tropischen Landwirishaft Und Veterinarmedizin 27 (3): 319328. (C.F. Horti. Abst. 61 (9), 7880).

Casallo, A.; J.M. Mateo; F. Sobrino (1991). Variedades tradicionales de cebolla cultivadas en España. Hortofruticultura, 2; 38-44.

Cheema, K.L.; A. Saeed and M. Habib (2003). Bulb yield and other economic traits in eight onion cultivars under different ecological zones of PunjabPakistan. International Journal of Agriculture \& Biology, 2: 188-190.

El-Damarany, A.M. and H.A. Obiadalla-Ali (2005). Growing five onion (Allium cepa L.) cultivars under two irrigation systems. Assiut J. Agric. Sci., 36 (6): 83-94.

El-Mofty, I.A.; M.A. Abd-Fattah; M.A. Badawi and S.A. Shehata (1983). Effect of fertilization and planting methods on yield components of onion Agricultural Research Review, 61 (8): 169-185.

El-Shafie, M.W.; M.M. El-Gammal and A.K. El-Kafory (1971). The development of two Egyptian onion varieties Giza 6 Mohassan and Behairy under Mallawy and Delta conditions. Vegetable Crops Third Conf. Alex. Univ.

Gamie, A.A. and I.A.A. Yaso (2007). Evaluation of some Egyptian onion genotypes in Sohag Governorate. J. Adv. Agric. Res. 12 (1): 77-85. 


\section{El-Feki,T.A. et al.}

Gamie, A.A.; K.A. Mohamed; K.A.O. El-Aref and M.M. Massoud (2000). Studies on some Egyptian onion varieties under Upper Egypt conditions. III- Effect of soil moisture condition on storability of some Egyptian onion genotypes. Assiut J. of Agric. Sci., 31 (5): 129-136.

Gomez, K.A. and A.A. Gomez (1984). Statistical procedures for Agricultural Research. 2nd Ed. John Wiley and Sons, Inc. New York.

Jones, H.A. and L.K. Man (1963). Onion and their allies. Interscience publishers, Inc., New York.

Landcaster, J.E.; E.P. McCartney; W.A. Jermyn and J.V. Johnstone (1995). Identification of onion cultivars for commercial production in Canterbury, New Zealand. New Yealand J. of Crop and Horticultural Science, 23: 299306.

Leilah, A.A.; S.A. El-Kalla; A.K. Mostafa and H. M. A. Afifi (2003). Performance of some local Egyptian onion strains under different planting dates. Scientific J. of King Faisal Univ. (Basic and Applied Sciences), 4 (1): 119 - 136.

Marey, R.A. and M.G. Morsy (2010). Performance and genetic parameters for some Egyptian onion genotypes evaluated under Sohag conditions. J. Plant Production, Mansoura University, 1 (8): $1153-1163$.

Miedema, P. (1994). Bulb dormancy in onion. 1-The effect of temperature and cultivar on sprouting and rooting. J. Hort. Sci., 69: 29-39.

Mohamed, E.I. and Gamie (1999). Evaluation of some organic fertilizers as substitutions of chemical fertilizers in fertilizing onion. Egypt. J. Appl. Sci., 14 (7): 664-678.

Mohamed, K.A. and A.A. Gamie (2000). Studies on some Egyptian onion varieties under Upper Egypt codition. 2- Effect of irrigation regime on yield and some bulb quality characters of onion varieties. Assiut J. of Agric. Sci., 31 (5): 115127.

Mohanty, B.K. and A. M. Prusti (2001). Performance of common onion varieties in kharif seasons. J. Tropical Agric., 39: 21-23.

Morsy, M.G.; R.A. Marey and L.S.M. Geries (2011). Genetic variability, heritability, genetic advance and phenotypic correlation in some onion varieties. $\mathrm{J}$. Agric. Res. Kafr El-Sheikh, 37 (1): 57-72.

Patil, R.S. and P.N. Kale (1991). Screening of onion cultivars for storage quality. Veg. Sci., 16 (1): 56-61.

Pavolic, N.; J. Zdravkovic; Sretenovic and T. Rajicic (2002). Variability and heritability of onion bulb fresh weight. Godisen Zbornik na Zemjodelskiot Fakultet Sv Kiril Metodij Skopje 47: 171-175.

Smittle, D.A. (1988). Evaluation of storage methods for "Granex" onions. J. of the Ameri. Soc. for Horti. Sci. 113: 877-880.

Snedecor, G.W. and W.G. Cochran (1980). Statistical Methods 7th Ed. lowa State Univ. Press, Ames., lowa U.S.A.

Tendaj M. and Gruszecki R. (2005). Current problems of onion set production. Nowości Warzywnicze/Vegetable Crops News 40: 21-24. [in Polish with English summary]. 
تأثير طرق الزراعة على الاتتاجية والقدرة التخزينية لبعض أصناف البصل المصرية

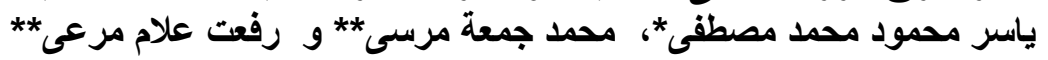

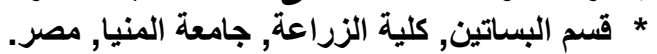
** قسم بحوث البصل, معهز بحوث المحاصيل الحقلية, مركز البحوث الزراعية, الجيزة, مصر.

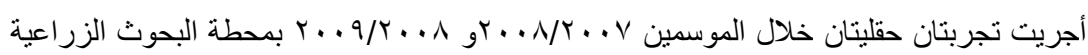

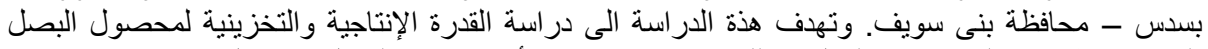

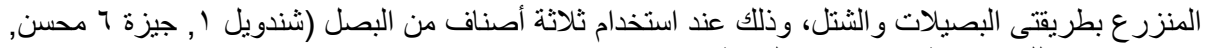

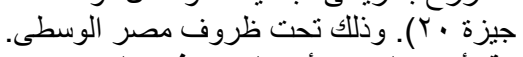

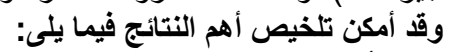

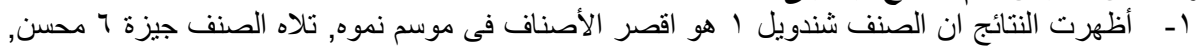

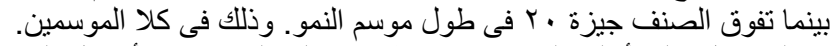

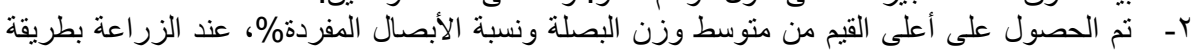

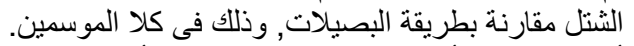

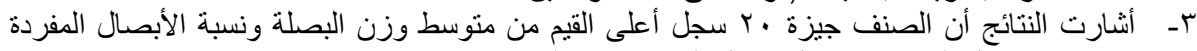

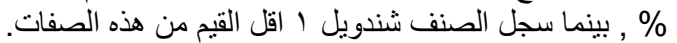

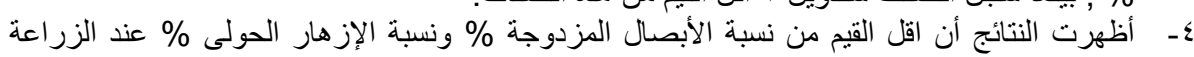

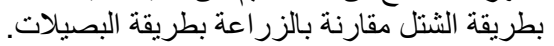

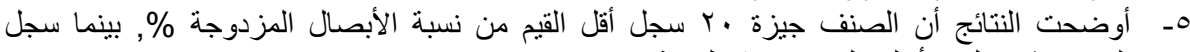

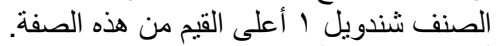

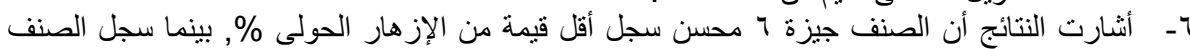
شندويل ا أعلى القيم من هذه الصنا الصفة.

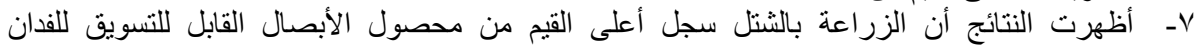

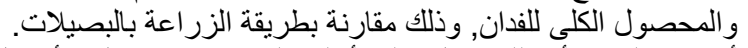

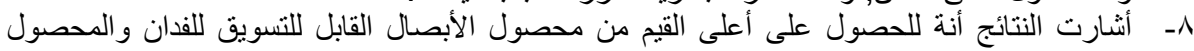

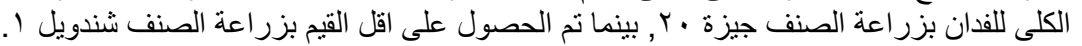

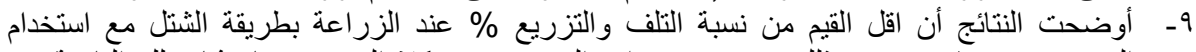

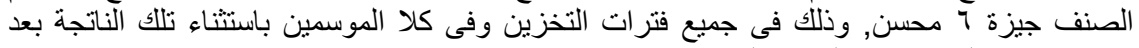

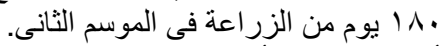

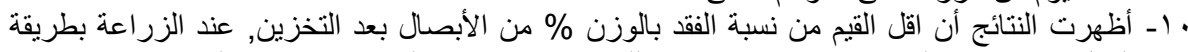

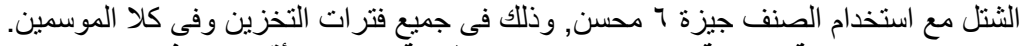

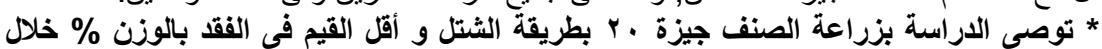

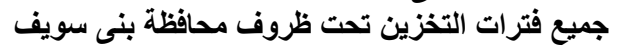

كلية الزراعة - جامعة المنصورة مركز البحوث الزراعية
قام بتحكيم البحث

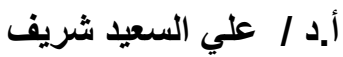
أ.د / مجدي أدي الدري حنا الله 